\title{
SELEKTIVITAS ALAT TANGKAP IKAN PARI DI PERAIRAN LAUT JAWA
}

\author{
Erfind Nurdin " dan Hufiadi" \\ 'Peneliti pada Balai Riset Perikanan Laut, Muara Baru-Jakarta
}

\begin{abstract}
ABSTRAK
Pengamatan di beberapa lokasi pendaratan ikan di pantai utara Jawa menunjukkan gill net dasar (lokal: jaring liongbun) dan rawai dasar tanpa umpan (lokal: pancing senggol) merupakan alat tangkap utama bagi ikan pari, sedangkan pada alat tangkap cantrang merupakan hasil tangkapan sampingan. secara teknis, gill net yang digunakan lebih selektif daripada cantrang, karena mempunyai ukuran mata jaring relatif besar (antara 40 sampai dengan $50 \mathrm{~cm}$ ) dibandingkan dengan cantrang. Demikian pula hasil tangkapannya. Cantrang tidak memiliki target hasil tangkapan yang lebih spesifik, baik terhadap jenis maupun ukuran ikan. Di perairan Cirebon, hasil tangkapan pancing senggol didominasi oleh ikan pari jenis Himantura gemardi dan $H$. bleekeri dengan ukuran lebar cawan antara 43 sampai dengan $96 \mathrm{~cm}$.
\end{abstract}

KATA KUNCI: alat tangkap, ikan parl, Laut Jawa

\section{PENDAHULUAN}

Indonesia diperkirakan merupakan negara yang paling tinggi dalam penangkapan menghasilkan ikan pari (ikan kelompok elasmobranchii). Pada umumnya nelayan memanfaatkan seluruh bagian Elasmobranchii, daging untuk dimakan, kulit untuk disamak, dan tulangnya dapat digunakan sebagai bahan baku pembuatan lem dan obat-obatan.

Sejalan dengan perkembangan jumlah penduduk dan meningkatnya permintaan akan bahan pangan berupa ikan, maka upaya peningkatan produksi ikan dari hasil tangkapan terus dipacu. Dari kondisi tersebut, maka jenis dan jumlah alat tangkap ikan yang digunakan semakin berkembang Perkembangan alat tangkap tersebut antara lain meliputi jumlah, dimensi, dan cara penangkapan ikan.

Selektivitas alat tangkap dapat diartikan sebagal kemampuan alat tangkap untuk memperoleh sasaran penangkapan ikan tertentu menurut jenis ikan, ukuran atau jenis kelamin (atau kombinasi ke-3) selama proses penangkapan berlangsung dan memungkinkan semua hasil tangkap sampingan (by catch) yang tidak diinginkan dapat diloloskan tanpa cidera (FAO, 1995). Alat tangkap ramah lingkungan merupakan alat tangkap yang tidak merusak habitat ikan (ekosistem akuatik) selama proses maupun sesudah kegiatan panangkapan ikan dilakukan.

Selektivitas alat tangkap adalah penting dalam hal menyeleksi ukuran panjang ikan pertama kali tertangkap (length at first capture) dan jenis ikan yang tidak menjadi target utama dalam penangkapan. Untuk tujuan pelestarian sumber daya ikan upaya penangkapan yang disarankan adalah menangkap ikan-ikan yang sudah pernah memijah. Dicerminkan oleh ukuran pertama kali tertangkap yang lebih besar dari ukuran pertama kali matang telur (Jength at first mature)
Dalam Code of Conduct for Responsible Fisheries (FAO, 1995) dihimbau agar penangkapan ikan oleh setiap negara terus dikembangkan dan menggunakan alat tangkap yang selektif dan ramah lingkungan untuk menjaga biodiversitas, struktur populasi, ekosistem akuatik, dan melindungi kualitas ikan.

Sudah sejak lama banyak nelayan di pantai utara Jawa yang mengkhususkan usaha penangkapan dengan target utama ikan pari. Alat tangkap yang digunakan berupa gill net dasar (lokal: jaring liongbun) dan rawai dasar tanpa umpan (lokal: pancing senggol), serta cantrang. Untuk mengetahui selektivitas dari ke-3 alat tangkap tersebut terhadap ikan pari, dilakukan penelitian di 2 lokasi yaitu Cirebon dan Tegal pada bulan April dan Juli 2003, dengan membandingkan komposisi hasil tangkapannya.

\section{GILL NET DASAR}

\section{Deskripsi Alat Tangkap}

Gil net dasar atau disebut juga jaring liongbun banyak ditemukan di daerah Cirebon dan Jakarta, pada umumnya mempunyai spesifikasi tertentu dengan ukuran mata jaring (mesh size) dan benang yang digunakan berukuran relatif lebih besar dibandingkan dengan gill net lain pada umumnya.

Hasil pengamatan menunjukkan deskripsi jaring sebagai berikut panjang jaring 100 sampai dengan 150 pis (panjang $80 \mathrm{~m}$ per pis) dengan lebar jaring 9 mata $( \pm 5 \mathrm{~m})$. Bahan jaring terbuat dari nylon multifilament diameter $3 \mathrm{~mm}$ dengan besar mata jaring (mesh size) antara 40 sampai dengan $50 \mathrm{~cm}$. Tali ris dan tali pelampung menggunakan bahan PE diameter antara 7 sampai dengan $8 \mathrm{~mm}$, dengan jarak antar pelampung $50 \mathrm{~cm}$. Pemberat yang digunakan berupa timah yang dipasang pada ris bawah dengan jarak antar pemberat $56 \mathrm{~cm}$ (Gambar 1). 


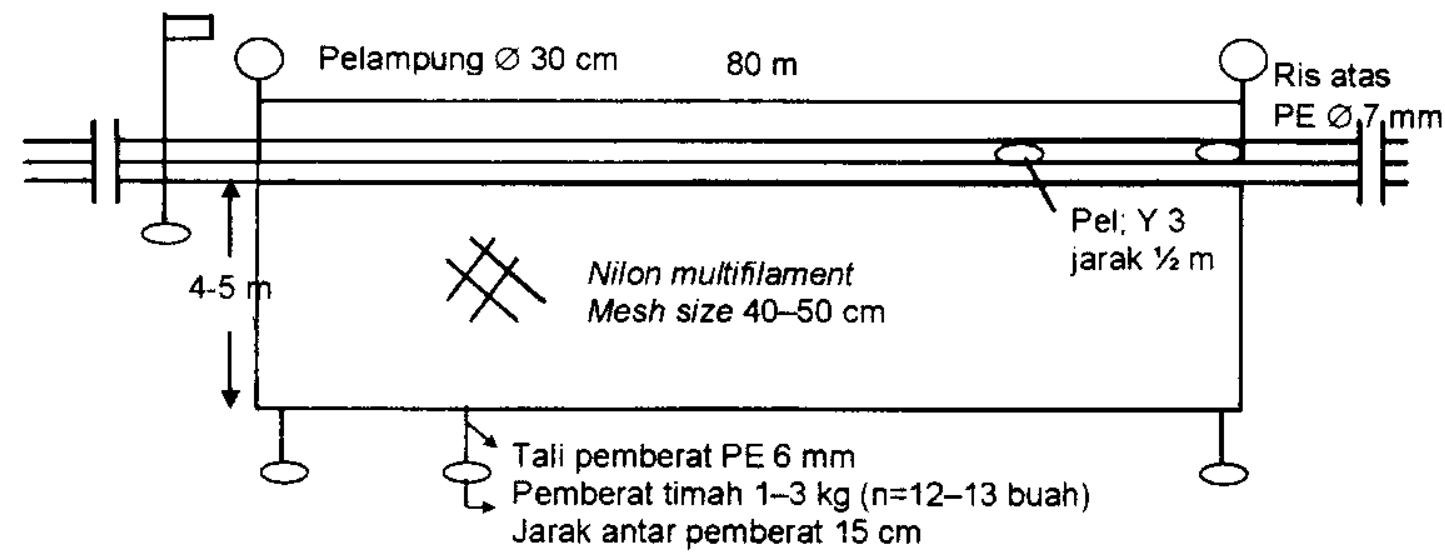

Gambar 1. Konstruksi gill net dasar (jaring liongbun)

Pengoperasian jaring liongbun pada prinsipnya menghadang arah gerak ruaya ikan sehingga ikan akan menabrak dan terjerat pada bagian insang atau terpuntal. Menurut (Baranov, 1914 dalam Sparre et al., 1989). Terdapat 3 cara ikan tertangkap dengan gill net, yaitu terjerat di bagian insang, badan terjepit oleh mata jaring dan terbetit akibat bagian tubuh yang menonjol (misal: rahang, gigi, dan sirip)

\section{Operasi Penangkapan}

Kapal yang menggunakan jaring liongbun terbuat dari kayu berukuran antara 80 sampai dengan 130 GT dengan ukuran: panjang $=25 \mathrm{~m}$, lebar $=7 \mathrm{~m}$, dan dalam $=2,5 \mathrm{~m}$. Mesin induk merek Nissan berukuran 8 silinder berkekuatan $125 \mathrm{PK}$ dan mesin bantu merek Dongfeng berkekuatan 25 PK. Satu hari penangkapan hanya melakukan 1 kali tawur (setting), dimulai antara pukul $16 .^{\circ 0}$ sampai dengan $18 .^{\circ 0}$ WIB. Penarikan jaring (hauling) mulai pukul $06^{00}$ sampai dengan selesai, tergantung banyak sedikitnya hasil tangkapan. Pada umumnya jaring dioperasikan pada kedalaman antara 30 sampai dengan $60 \mathrm{~m}$. Lama di laut dalam 1 trip berkisar antara 40 sampai dengan 90 hari. ABK berjumlah 10 sampai dengan 12 orang. Daerah operasi meliputi perairan utara Jawa sampai dengan Kalimantan bagian selatan (Pulau Laut), Sumatera (Sibolga), dan Papua (Merauke)

\section{Komposisi Hasil Tangkapan}

Observasi pada kapal jaring liongbun di Laut Jawa khususnya di sekitar perairan Cirebon pada bulan Juli 2003 diperoleh 3 famili ikan pari yang tertangkap. yaitu Dasyatidae, Myliobatidae, dan Rhinobatidae. Hasil tangkapan terbanyak $(79,2 \%$ dari total tangkapan) terdapat pada famili Dasyatidae dan paling sedikit $(5,9 \%)$ pada famili Myliobatidae (Tabel 1).

Tabel 1. Hasil tangkapan ikan pari dengan jaring liongbun di perairan Cirebon, bulan Juli 2003

\begin{tabular}{|c|c|c|c|c|c|c|c|}
\hline \multirow[t]{2}{*}{ No. } & \multirow[t]{2}{*}{ 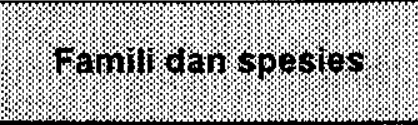 } & \multicolumn{2}{|c|}{ 1.2. } & \multicolumn{2}{|c|}{ 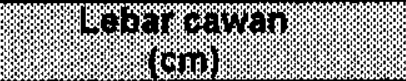 } & \multicolumn{2}{|c|}{ yngk } \\
\hline & & 8 & $1 \%$ & 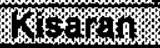 & 2 ram & 12 & $\%$ \\
\hline \multirow[t]{9}{*}{1} & Famili Dasyatidae & & & & & & \\
\hline & Himantura gerrardi & 40 & 61 & $40-100$ & 51,7 & 101 & 37,4 \\
\hline & H. bleekeri & 2 & 3 & $79-104$ & 92,8 & 5 & 1,9 \\
\hline & Himantura jenkinsii & 9 & 24 & $48-92$ & 64,5 & 33 & 12,2 \\
\hline & Himantura undulata & 5 & 7 & $56-143$ & 82,1 & 12 & 4,4 \\
\hline & Himantura fai & 14 & 23 & $132-160$ & 145,6 & 37 & 13,7 \\
\hline & Dasyatis fluviorum & 3 & 6 & $50-110$ & 75,3 & 9 & 3,3 \\
\hline & Taeniura meyeni & 5 & 8 & $53-64$ & 58,5 & 13 & 4,8 \\
\hline & Urogymnus asperrimus & 0 & 4 & $196-220$ & 203,8 & 4 & 1,5 \\
\hline \multirow[t]{2}{*}{2} & Famili Myliobatidae & & & & & & \\
\hline & Aetomylaeus maculatus & 0 & 16 & $134-160$ & 146,9 & 16 & 5,9 \\
\hline \multirow[t]{4}{*}{3} & Famili Rhinobatidae & & & & & & \\
\hline & Rhynchobatus djiddensis & 3 & 12 & $80-112^{\circ}$ & 98,9 & 15 & 5,6 \\
\hline & Rhynchobatus anclyostoma & 7 & 18 & $65-132^{*}$ & 95 & 25 & 9,3 \\
\hline & Jumlah & 98 & 182 & & & 270 & 100,0 \\
\hline
\end{tabular}


Ditinjau dari sex ratio diperoleh rata-rata jumlah ikan betina lebih banyak dari ikan jantan. Lebar cawan terkecil $51,9 \mathrm{~cm}$ diperoleh untuk jenis Himantura gerrardi dan terbesar $203,8 \mathrm{~cm}$ pada jenis Urogymnus asperrimus (Tabel 1). Hasil tangkapan didominasi oleh ikan pari $(83,4 \%)$ dari total hasil tangkapan, diikuti oleh jenis ikan demersal lainnya seperti cucut $(6,2 \%)$, layaran $(5,7 \%)$, manyung $(2 \%)$, dan lain-lain $(2,7 \%)$.

\section{RAWAI DABAR (PANCING SENGGOL)}

\section{Deskripsi Alat Tangkap}

Rawai dasar untuk menangkap ikan pari yang digunakan nelayan di Cirebon, dikenal dengan nama pancing senggol. Desainnya sederhana di mana pada tali utama (main line) dipasang secara berderet dengan jarak tertentu tali cabang (branch line) yang ujungnya diberi mata pancing

Alat ini dioperasikan tanpa menggunakan umpan yaitu dengan cara menghadang arah gerak renang ikan yang akan mengenai mata pancing atau tersangkut di bagian badan (cawan). Bedasarkan pada hasil pengamatan diperoleh spesifikasi pancing sebagai berikut jumlah mata pancing antara 7.000 sampai dengan 10.000 buah dengan ukuran mata pancing No. 4 .

Tali utama (main line) PE diameter $3 \mathrm{~mm}$, tali cabang (branch line) PE berdiameter $2,5 \mathrm{~mm}$ dengan panjang tali $32 \mathrm{~cm}$. Jarak antar pancing 32 sampai dengan $34 \mathrm{~cm}$. Pelampung spon (berukuran $2,5 \mathrm{~cm} \times$ $3,5 \mathrm{~cm}$ ) dengan jarak setiap 6 mata pancing. Pemberat batu (@ $250 \mathrm{~g}$ ) dipasang menggantung pada setiap 100 mata pancing. Pada setiap 1.500 mata pancing diberi bendera sebagai pelampung tanda. Agar pancing berada di dasar perairan selain digunakan pemberat dari batu digunakan pula jangkar 2 buah (Gambar 2).

\section{Operasi Penangkapan}

Kapal yang digunakan berukuran panjang $10 \mathrm{~m}$. lebar $2,7 \mathrm{~m}$ dan dalam 1,50 m, mesin dongfeng $30 \mathrm{PK}$ dengan jumlah $A B K 4$ orang. Pengoperasian dilakukan pada malam hari. Setting mulai pukul $18^{\circ}$ sampai dengan $19 .^{30}$ WIB dioperasikan pada kedalaman antara 3 sampai dengan $20 \mathrm{~m}$ pada umumnya 7 sampai dengan $12 \mathrm{~m}$. Hauling mulai pukul $03{ }^{\circ 0} \mathrm{~W} I \mathrm{~B}$, selama 2 sampai dengan 5 jam tergantung hasil tangkapan. Trip yang dilakukan skala harian dan hanya dilakukan 1 kali setting per trip. Daerah operasi di sekitar perairan Cirebon dan Tegal dengan waktu tempuh antara 3 sampai dengan 4 jem.

\section{Hasil Tangkapan}

Pengukuran individu ikan pari yang tertangkap dengan pancing senggol di perairan Cirebon mempunyai kisaran lebar cawan (WD) antara 35 sampai dengan $110 \mathrm{~cm}$ (Tabel 2). Lebar cawan terkecil $43,8 \mathrm{~cm}$ terdapat pada jenis Himantura gerrardi dan terbesar $96,25 \mathrm{~cm}$ pada jenis Himantura bleekeri. Hasil tangkapan didominasi oleh Himantura gerrardi $(36 \%)$. Observasi pada kapal yang mengoperasikan pancing senggol di perairan Cirebon menunjukkan $100 \%$ hasil tangkapan berupa ikan pari.

\section{CANTRANG}

Cantrang dan sejenisnya memegang peranan penting dalam perikanan tradisional di perairan utara Jawa. Di Tegal dikenal dengan nama cantrang besar. Pada prinsipnya cantrang terdiri atas kantong (cod end) badan, sayap, dan mulut (Subani \& Barus, 1988)

\section{Deskripsi Alat Tangkap}

Spesifikasi umum cantrang yang dioperasikan di perairan Tegal sebagai berikut panjang sayap $15 \mathrm{~m}$, tali ris atas diberi pelampung 3 buah dari bahan fibre

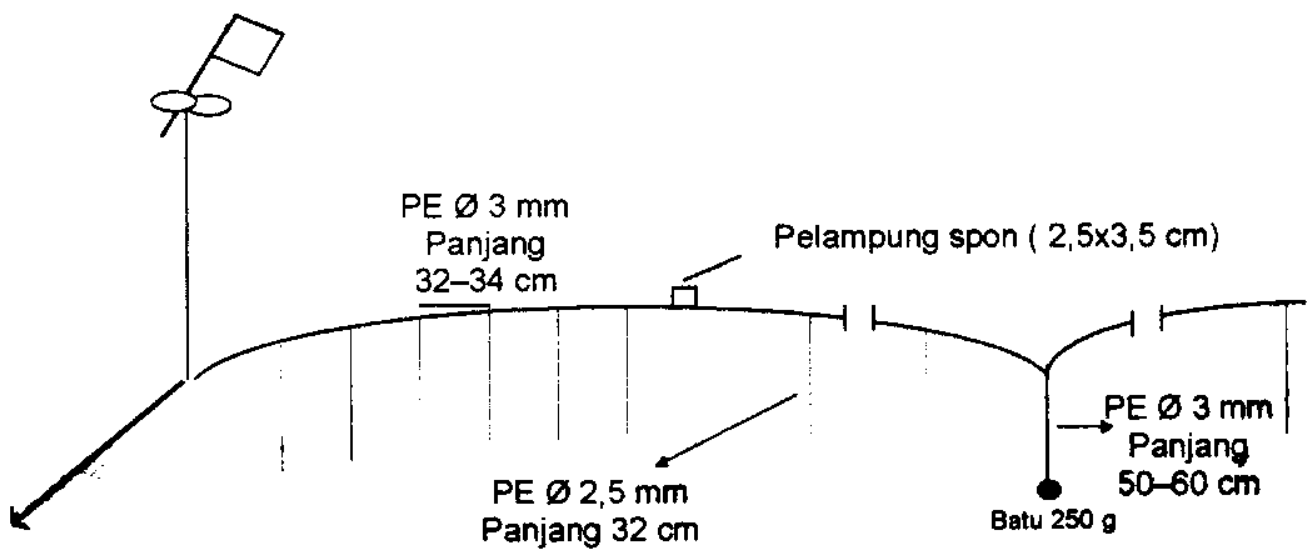

Gambar 2. Konstruksi rawai dasar pari. 
Tabel 2. Hasil tangkapan ikan pari dengan rawai dasar di Cirebon, bulan Juli 2003

\begin{tabular}{|c|c|c|c|c|c|c|c|}
\hline \multirow[t]{2}{*}{10} & \multirow[t]{2}{*}{ H47Ifognspeises } & \multicolumn{2}{|c|}{ \%arar } & \multicolumn{2}{|c|}{ '. } & \multicolumn{2}{|c|}{ matar } \\
\hline & & \% & 1 & $8<1+1$ & 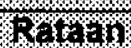 & $n$ & 6 \\
\hline \multirow[t]{6}{*}{1} & Famili Dasyatidae & & & & & & \\
\hline & H. gerrardi & 5 & 3 & $35-62$ & 43,8 & 8 & 36,4 \\
\hline & H. bleekeri & 2 & 2 & $89-104$ & 96,3 & 4 & 18,2 \\
\hline & H. jenkinsii & 1 & 2 & $66-80$ & 72,7 & 3 & 13,6 \\
\hline & H. undulata & 1 & 1 & $60-110$ & 85,0 & 2 & 9,1 \\
\hline & Dasyatis fluviorum & 2 & 2 & $40-70$ & 55,5 & 4 & 18,2 \\
\hline \multirow[t]{3}{*}{2} & Famili Myliobatidae & & & & & & \\
\hline & Aetobatus narinan & 1 & 0 & 122 & 122 & 1 & 4,5 \\
\hline & Jumlah & 12 & 10 & & & 22 & 100,0 \\
\hline
\end{tabular}

berdiameter $24 \mathrm{~cm}$ dan pada tali ris bawah diberi pemberat timah dan batu berbobot $11,5 \mathrm{~kg}$. Semua bagian jaring terbuat dari benang nilon $\mathrm{d} / 12$ dengan besar mata jaring (mesh size) berturut-turut 6 inci pada bagian sayap sampai dengan 1 inci pada kantong (Gambar 3).

\section{Operasi Penangkapan}

Cantrang dioperasikan dengan kapal berukuran 35 GT panjang $15 \mathrm{~m}$, lebar $6,5 \mathrm{~m}$, dan dalam $2 \mathrm{~m}$ yang dilengakapi mesin penggerak berkekuatan $160 \mathrm{PK}$ serta mesin pembantu diesel 20 PK. Lama operasi di laut pada umumnya dilakukan antara 15 sampai dengan 25 hari.

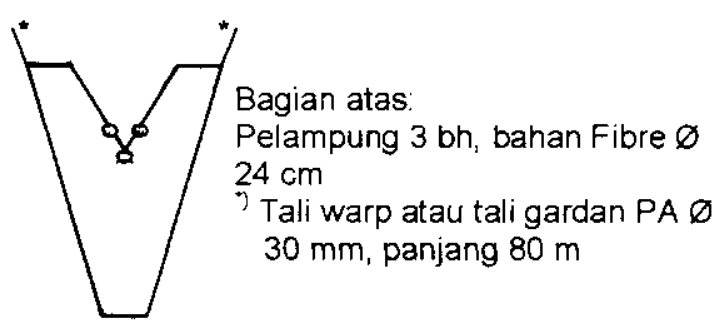

A

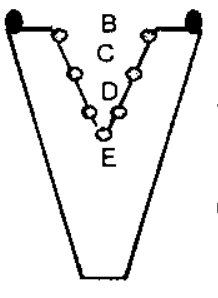

Bagian bawah

A. Pemberat batu $5 \mathrm{~kg}$, untuk membuka mulut jaring

B. Pemberat timah $1 \mathrm{~kg}$

C. Pemberat timah $1 \mathrm{~kg}$

D. Pemberat timah $1,5 \mathrm{~kg}$

E. Pemberat timah $3 \mathrm{~kg}$

\section{Hasil Tangkapan}

Pengukuran individu ikan pari yang tertangkap cantrang di perairan Tegal diperoleh kisaran lebar cawan (WD) antara 12 sampai dengan $166 \mathrm{~cm}$. Lebar cawan terkecil $(17,9 \mathrm{~cm})$ diperoleh pada jenis Dasyatis zugei dan terbesar $(144,7) \mathrm{cm}$ pada jenis Dasyatis thetidis (Tabel 3)

Dari ke-3 alat tersebut yang komposisi jenis hasil tangkapannya bervariatif adalah cantrang. Alat tangkap cantrang tidak selektif dan cara pengoperasiannya bersifat aktif yaitu ditarik dari sebuah kapal yang bergerak sehingga daerah yang tersapu lebih luas. Hasil tangkapan pada umumnya

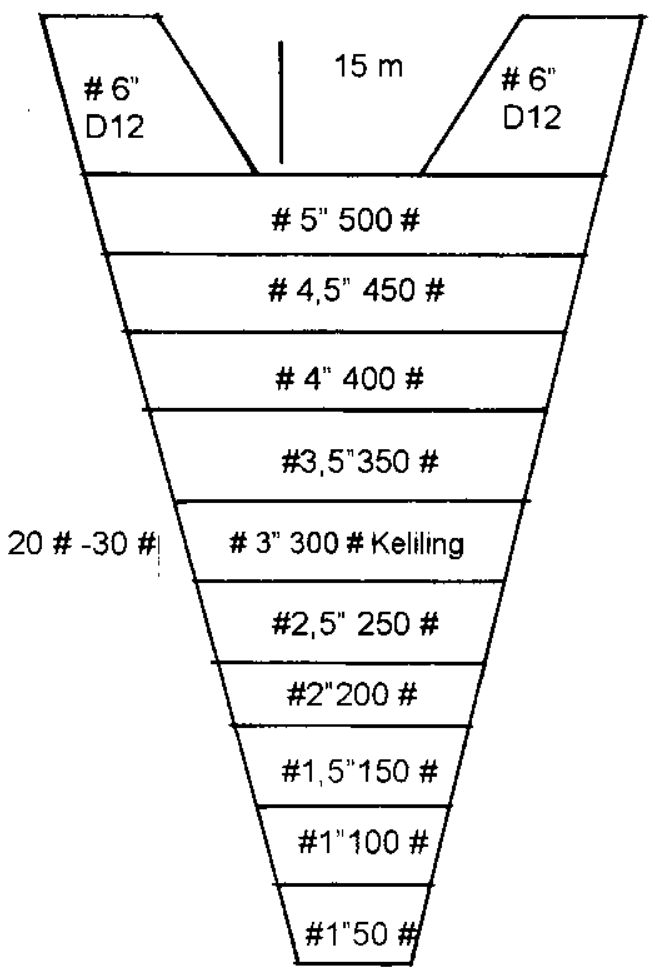


Tabel 3. Hasil tangkapan ikan pari dengan jaring cantrang di perairan Tegal, bulan April 2003

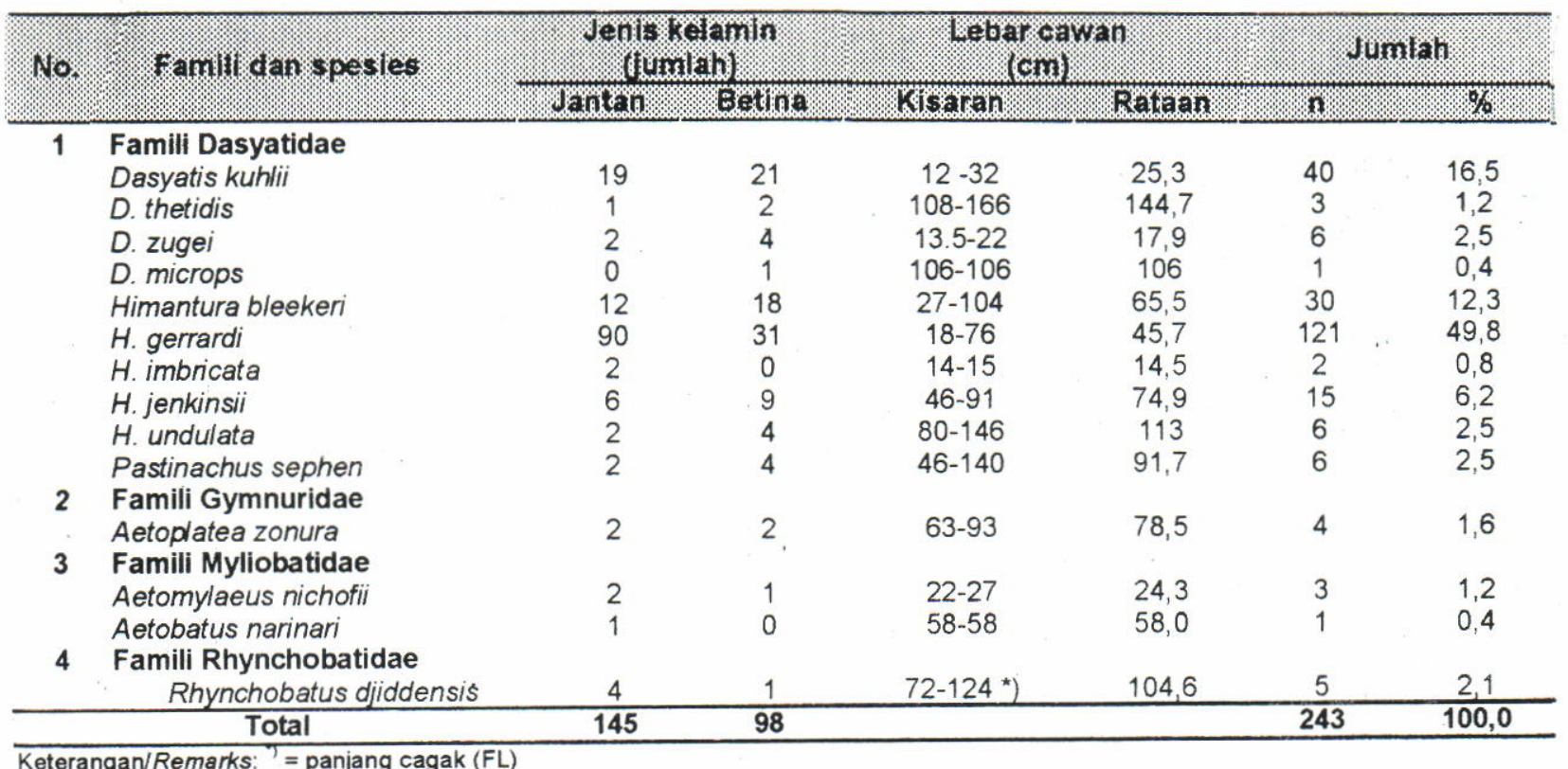

berupa ikan demersal. Pengamatan di daerah Tegal, ikan pari relatif sedikit $1,4 \%$ dari total hasil tangkapan. Hasil tangkapan tertinggi (20\%) berupa ikan kurisi (famili Nemipteridae), peperek (famili Leioghnatidae) $12 \%$, beloso (famili Synodontidae) $11,3 \%$, kapasan (famili Gerreidae) 6\%, ikan sebelah (famili Psettodidae) 4,1\%, layur (famili Trichyuridae) $4 \%$, dan lainnya rata-rata kurang dari $4 \%$.

\section{SELEKTIVITAS ALAT TANGKAP}

Selektivitas alat tangkap adalah fungsi alat tangkap untuk menangkap organisme (ikan) yang terbatas pada spesies tertentu dan kisaran ukuran tertentu dalam suatu populasi yang ditemui di daerah penangkapan tertentu (Arimoto, 1999). Hasil tangkapan cantrang menunjukkan jenis maupun ukuran ikan yang tertangkap sangat beragam, dengan demikian cantrang tidak mempunyai target yang spesifik atau dapat disebut bahwa cantrang merupakan alat tangkap yang tidak selektif baik terhadap jenis maupun ukuran hasil tangkapan.

Jaring liongbun dan pancing senggol lebih selektif terhadap ukuran ikan dan hasil tangkapan sampingan (by catch). Dimensi pancing senggol menunjukkan jarak antar pancing antara 32 sampai dengan $34 \mathrm{~cm}$ dan dioperasikan tanpa umpan sehingga yang tertangkap hanya pari yang bercawan relatif lebar. Demikian juga, jaring liongbun yang memiliki ukuran mata jaring relatif besar yaitu antara 40 sampai dengan $50 \mathrm{~cm}$ sehingga ikan yang tertangkap berukuran relatif besar.

\section{DAERAH PENANGKAPAN}

Penangkapan pari di pantai utara Jawa dilakukan sepanjang tahun. Pari sering tertangkap oleh ke-3 alat

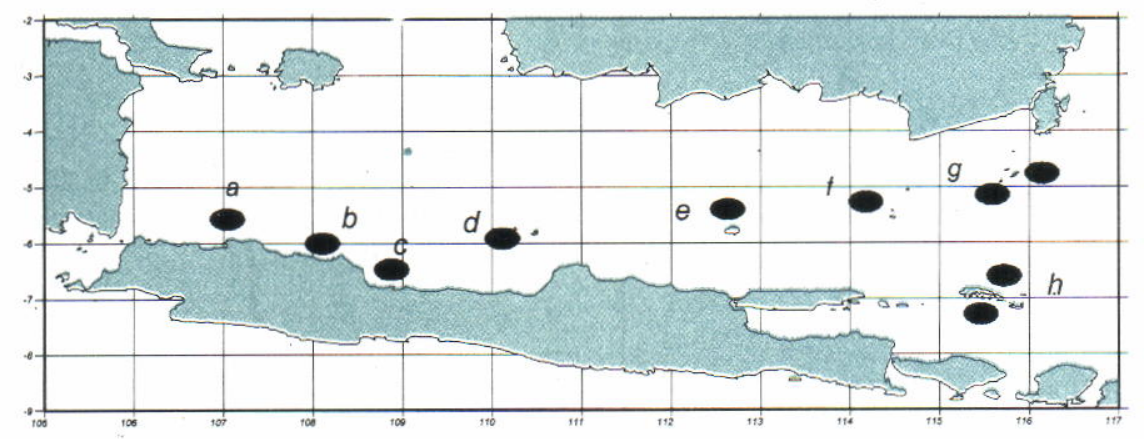

Keterangan/Remaks: a. Kerawang, b. Indramayu, c. Cirebon, d. Karimun Jawa, e. Bawean, f. Masalembu, g. Matasiri, h. Kangean.

Gambar 5. Lokasi penangkapan pari di Laut Jawa 
tangkap tersebut di sekitar perairan dengan dasar berpasir, lumpur, atau dasar pasir berlumpur. Berbagai jenis pari menempati habitat di dekat pantai dan paparan benua, teluk pantai berpasir, teluk berlumpur, dan muara sungai (Compagno, 1984).

Nelayan rawai dasar yang berbasis di Cirebon beroperasi di sekitar perairan Indramayu, Cirebon sampai dengan perbatasan Tegal yaitu di perairan Losari. Nelayan gill net dasar dan cantrang beroperasi di perairan Karimun Jawa, Karawang, Bawean, Matasirih, Masalembo, dan Kangean. Lokasi penangkapan ikan pari dapat dilihat pada Gambar 5.

\section{KESIMPULAN}

1. Jaring liongbun (bottom gill net) dan pancing senggol (bottom long line), merupakan alat tangkap utama untuk penangkapan ikan pari sedangkan cantrang (danish saine) target penangkapan berupa ikan demersal termasuk pari.

2. Cantrang tidak termasuk alat tangkap yang selektif terhadap ikan pari, dengan hasil tangkapan ikan pari berkisar antara 1 sampai dengan $5 \%$. Pari yang tertangkap berukuran kecil sampai dengan besar (lebar cawan antara 12 sampai dengan 166 $\mathrm{cm}$ ).
3. Jaring liongbun dan pancing senggol merupakan alat tangkap yang selektif terhadap jenis ikan maupun ukuran ikan pari yang tertangkap.

\section{DAFTAR PUSTAKA}

Arimoto T. 1999. Fish Behaviour for improving fish capture technology. Tokyo University of Fisheries. Japan. $55 \mathrm{p}$.

Compagno, L. J. V. 1984. FAO Species catalogue. Vol.4. Sharks of the world. An annotated and illustrated catalogue of shark species known to date. Part 1. Hexanchiformes to Lamniformes: viii. 1-250. Part 2. Carcharhiniformes: 251-655. FAO Fisheries Synopsis. 125: 1-655.

FAO. 1995. Code of conduct for responsible fisheries. FAO. Rome. $41 p$.

Sparre, P., E. Ursin. \& S. C. Venema. 1989 Introductin to tropical fish stock assessment. Part I. Manual FAD Fish. Tech. Pap. 306/l Rome. Italy.

Subani, W. \& H. R.Barus. 1988. Alat penangkapan ikan dan udang laut oi indonesia. Balai Penelitian Perikanan Laut: Jakarta. 